\title{
Naturally Derived Formulations and Prospects towards Cancer
}

\author{
Neha Masarkar, Sukhes Mukherjee, Sudhir K. Goel, Rajeev Nema* \\ All India Institute of Medical Science (AIIMS), Bhopal (Madhya Pradesh), India \\ Email: *rajeevnema07@gmail.com
}

How to cite this paper: Masarkar, N., Mukherjee, S., Goel, S.K. and Nema, R. (2019) Naturally Derived Formulations and Prospects towards Cancer. Health, 11, 971-997. https://doi.org/10.4236/health.2019.117078

Received: February 28, 2019

Accepted: July 27, 2019

Published: July 30, 2019

Copyright $\odot 2019$ by author(s) and Scientific Research Publishing Inc. This work is licensed under the Creative Commons Attribution International License (CC BY 4.0).

http://creativecommons.org/licenses/by/4.0/

\begin{abstract}
Traditional Medicine (TM) and their secondary metabolites are being increasingly recognized as useful complementary treatments toward the cancer. A large number of clinical studies have reported and proven concern of cancer patients. Here we have also reported recent studies on the biochemical and cellular mechanisms of Traditional Medicine (TM). Nowadays, Chemotherapy and surgery are standard methods for treatment of cancer, but still it's not been fully successful. Some progress has been made in cancer diagnosis and treatment, but high incidence rate of cancer and low survival rate of patient are still being reported worldwide. Since ancient times, a number of traditional medicines known as Ayurveda, Siddha, Unani, Iranian, Chinese, Korean, acupuncture, Muti, Ifa, and African medicine are widely used for therapeutic purposes and are becoming popular as Traditional Medicine (TM). It has been reported that plants synthesize plethora of "secondary metabolites" or "phytochemicals", proven to possess anti-mutagenic and anti-cancer properties in many research studies. There are many possibilities for further organized research for screening of medicinal plants for their potential and efficacy against chronic diseases such as a cancer and other inflammatory diseases. Therefore, researcher's interest should be in identification and standardization of new anti-cancer drug with low side effects and greater efficacy, that is easily acceptable in medical community and which may overcome the challenges in present and future cancer therapy. This review explores therapeutic value of certain bio-active principals of plant which could serve as potential pharmacologically active drug for treatment of cancer in future.
\end{abstract}

\section{Keywords}

Bio-Active Principles, Cancer, Chemotherapy, Phytochemicals, Secondary Metabolites 


\section{Introduction}

\subsection{Conventional Cancer Therapy}

Cancer is a state which arises when cells start dividing in an uncontrolled manner disobeying the check mechanisms, which controls the rate of cell proliferation leading to the formation of a neoplastic tumor, which may be benign or malignant. Cancer arises mainly due to two reasons: one is Gain of function of a proto-oncogene, which makes it oncogenic and second is Loss of function of a tumor suppressor gene [1]. Despite the latest advancements in the cancer treatment it remains a key cause of death worldwide [2]. Current treatment includes chemotherapy, radiations and surgery, out of which chemotherapy is most common. Most successful chemotherapeutic agents include: Taxanes-paclitaxel (Taxol), docetaxel (Taxotere), albumin bound paclitaxel (Abraxane), Anthracyclines-doxorubicin, pegylated liposomal doxorubicin, epirubicin, Platinum agents-cisplastin, carboplastin etc. All these agents cause serious side effects [3] [4] [5], which includes kidney, liver, nerve and blood vessel damage, hearing loss, lower blood count etc. [6] [7], regional toxicity affecting mucosa cells, causing irritative urinary and blood loss [7]. Later toxic effects include damage to proliferating cells such as fibroblasts, endothelial and parenchymal cells [7]. Other undesired side effects such as immune suppression, bone necrosis, lung fibrosis and skin devascularization are seen with all conventional therapies [5] [6] [7] [8]. Although the desired goal of chemotherapy is to eliminate the tumor cells, diverse range of normal cells is also affected, leading to many adverse side effects on multiple organ systems [9]-[14]. Such debilitating effects and toxicity are a major clinical problem which limits the usefulness of anticancer agents [15] [16]. Knowing how the chemotherapeutic agents work is important in predicting its side effects. For instance, treatment with alkylating agents and topoisomerase II inhibitors increases the risk of secondary cancer (acute leukaemia); anthracyclines (like doxorubicin) induce cardiotoxicity; and mitotic inhibitors have the potential to cause peripheral nerve damage [17]. Over $75 \%$ of cancer patients suffer from therapy associated fatigue, nausea, vomiting, pain, rashes, infection, headaches, which considerably decreases the quality life of the patients [3] [13] [15] [18] [19]. They also affect the nutritional status of the patients [3] [18] causing malnutrition, which is one of the major reasons why cancer patients die [6] [18]. Ongoing researches on several secondary metabolites are under clinical trials for the treatment of various diseases including cancer. TM/CAM and its derived compounds are an essential aspect for therapeutics, and nano-particles based approaches could be a new hope for additional therapy for cancer treatment [20].

\subsection{Ancient History of Traditional Medicine}

From ancient times, traditional medicinal plants are being used for treatment of various diseases [21]. Natural medicine sometimes referred to as herbalism or botanical medicine is the use of plants for their therapeutic or medicinal value 
and has been used by many cultures throughout history [22]. The oldest written facts about medicinal plants and the uses of plants are contained in thousands of poetic hymns in the Rig Veda. The first school to teach Ayurvedic medicine was at the University of Banaras in 500 BC where the great Samhita (or encyclopedia of medicine) was written. Another great enclyclopedia was written 700 years later, and these two together forms the basis of the Ayurveda or Indian medicinal plant concept [23]. The different indigenous system of medicine namely Ayurveda, Siddha, Unani, Iranian, Chinese, Korean, acupuncture, Muti, Ifa, and African medicine have been in existence and used in several countries for treatment. These systems of medicine provide to the needs of nearly $70 \%$ of the population residing in the villages. Apart from India, these systems of medicine are prevalent in China, Korea, Middle Eastern, European, Africa and America and many other countries [24] [25]. India has a rich culture of using medicinal herbs and spices, which includes about more than 2000 species and has a vast geographical area with high potential abilities to be used as traditional medicines but only very few have been considered chemically and pharmacologically for their prospective medicinal value [26]. In 1819, morphine, codeine and paregoric acid were isolated which laid down the foundation for isolation of pharmacologically active compounds. Even today, morphine remains the standard for measuring synthetic analgesic drugs. In addition U.S. based research has proved the medicinal properties of alkaloids from Madagascar periwinkle (Catharanthus roseus), used in the chemotherapy of childhood leukemia and for the treatment of Hodgkin's disease (Taxus brevifolia), and approved by FDA in 1992. As per our recent knowledge about $25 \%$ to $30 \%$ of the prescribed drug contains at-least one or two active ingredients derived from plants [27]. Many drugs listed as conventional medications were originally derived from plants [28]. Salicylic acid, a precursor of aspirin, was originally derived from "white willow bark" and "meadowsweet plant" [29]. Other plant derived drugs include the anti-malarial "quinine" extracted from the bark of Cinchona species. "Vincristine" used in cancer treatment is derived from "Madagascar periwinkle" (Catharanthus roseus) [30].

\subsection{Traditional Medicine}

The use of traditional medicine (TM) and complementary and alternative medicine (CAM) as therapeutics is growing all over the world [31]. Already, it accounts for a major part of the health care provided worldwide. In low- and middle-income countries, up to $80 \%$ of the population relies on TM for their primary health care needs [32]. In many high income countries CAM utilization is becoming increasingly popular, with up to $65 \%$ of the population reported that they have used this form of medicine [32] [33]. Today plant based drugs play an essential role in health care. According to $\mathrm{WHO}, 80 \%$ of the world population rely on traditional medicines for primary health care [34]. Currently 119 chemicals derived from 90 plant species constitute major drugs. Studies showed that plant derived drugs represent about $25 \%$ of the American drug market [35]. 
There are more than 250,000 plant species in world with unique secondary constituents [36], however, only few of them have been investigated for their potential value as a drug. Furthermore, medicinal plants typically contain mixtures of different phytochemicals that may act individually, additively or in synergy to improve health [37] and enhance mood and give a sense of well-being [38]. Now we have enough scientific reasons for using TM/CAM as a more effective therapy in comparison to conventional medicines. Apart from therapy some Indian and African communities, traditional medicines are thought to help clean out negative spiritual influences [39] and supporters of TM/CAM use them frequently as they are generally safe at common doses [40]. More than 3000 plants based secondary metabolite worldwide have been clinically reported to have anticancer properties [41] [42]. TM/CAM medicine use is still common in oncology therapy worldwide [43] [44]. In the last two decades, the use of herbal remedies has also been widely increased in many developed countries as TM/CAM. Secondary metabolite have increasing attention in cancer chemotherapy because they are viewed as more biologically active target sites and are less toxic to normal cells [45]. Moreover, there is evidence that natural product-derived anticancer drugs have alternative modes of promoting cell death [46] [47]. In fact, the use of TM/CAM based metabolite as the background to discover and develop a drug entity is still a research attention.

\subsection{WHO Traditional Medicine Strategy}

According to WHO definition of traditional medicine (TM) is as follows "Diverse health practices, approaches, knowledge, beliefs incorporating plant, animal, and/or mineral based medicines, spiritual therapies, manual techniques and exercises applied singularly or in combination to maintain well-being, as well as to treat, diagnose or prevent illness" [48]. TM is a comprehensive word used to refer many systems of traditional medicine and other various forms of local medicines.

In developed and developing countries where the dominant health care systems look forward on allopathic medicine, apart from conventional approach now scientist are thinking toward traditional medicine (TM) and these medicine often termed as "complementary" alternative" or "non-conventional" medicine. Herbal medicine includes herbs and plant active ingredients or plant secondary metabolites. In addition general sense to all above mentioned regions for Traditional Medicine/Complementary alternative medicine (TM/CAM) is still in used [48] for their healthcare purposes. In many parts of the world expenditure on TM/CAM is increasing rapidly. The mission of WHO for essential drugs and medicine policy is that: it helps to save lives and improve healthcare facilities by healing the huge gap between the potential that essential drugs have to offer towards patient care patients care. In most developing countries, national TM/CAM institutes have been established, like in India, China, North and South Korea, Ghana, Indonesia, Mali, Madagascar, Nigeria, Sri Lanka, Thailand, Viet- 
nam and list goes on. In addition WHO also provides guidelines, scientific information and research grant into the safety and efficacy of use of TM/CAM.

According to WHO TM strategy, the functions of WHO in TM/CAM can be outlined as follows (WHO traditional medicine strategy: 2014-2023):

- Facilitating integration of TM/CAM into national healthcare systems by helping member states to develop their own national policies on TM/CAM.

- Producing guidelines for TM/CAM by developing and providing international standards, technical guidelines, and methodologies for research into TM/CAM therapies and products, and for use during manufacture.

- Stimulating strategic research into TM/CAM by providing support for clinical research projects on safety and efficacy of TM/CAM, particularly with references to diseases such as malaria and HIV/AIDS.

- Advocating the rational use of TM/CAM by promoting evidence based TM/CAM.

- Managing information on TM/CAM by acting as a clearing house to facilitate information exchange on TM/CAM.

\subsection{Formulation Development and Discovery}

Discovery of TM/CAM drugs has become one of the main areas of interest in pharmacological research [1] [45] During the last few years, the development of active compounds (plant secondary metabolites) based drugs has risen significantly, this can, in part, be attributed to the new technologies in natural product isolation and purification, combinatorial synthesis and high-throughput screening [49]. Natural products from dietary components such as Indian spices and medicinal plants are known to possess antioxidant activity. Recently, more than 100 new active compounds have been isolated as anti-cancer agents from plant sources [1]. Drug development is an essential part of research owing to low bio-availability of flavonoids and their lack of stability, excessive metabolism, permeability problems, lack of site specificity in distribution, rapid elimination etc. The scope of this review is to assess and put into perspective salient features of some recently reported work on Plant secondary metabolites including the methylated compounds that showed improved drug like properties [50]. Nowadays a number of approaches are being considered for selecting higher plants as reference for anti cancer drug development with the aim of drug accomplishment, and to highlight the role of ethno medicine [51]. During the last few decades, a wide range of anti-cancer agents were discovered from plants, but only a few of them managed to reach clinical use, from their successful chemical identification, to their effectiveness in therapeutic cancer treatment. Each of them has their advantages and limitations. Few of them approved by FDA are Vincristine [52], Paclitaxel [53] [54], Homoharringtonine [55], Curcumin [56] and Betulinic Acid [57]. All of them are derived from natural products [58].

\subsection{Active Secondary Metabolites}

Phytochemicals (plant secondary metabolites) are bioactive substances or active 
ingredients of plants which are responsible for its biological and medicinal properties [59]. They have found to be associated in the protection of humans against chronic degenerative diseases [60]. The term "Phytochemical" according to American Cancer Society refers to a wide variety of compounds produced by plants and can be found in fruits, vegetables, beans, grains etc. The isolated active compounds from these plants are used for applied research. Some of the plant chemicals are: flavonoids, alkaloids, saponins, tannins, cardiac glycosides, antharquinones, sterols and triterpenes etc. [61].

- Flavonoids: Flavonoids are water soluble polyphenolic molecules containing 15 carbon atoms and is the most studied phytochemical. They can be visualized as two benzene rings which are joined together with a three carbon chain. One of the carbons of the short chain is always connected to a carbon of one of the benzene rings, either directly or through an oxygen bridge, thereby forming a third middle ring [62]. They can be classified into six major sub-groups: flavones, flavonols, flavanones, catechins, anthocyanidins and isoflavones [63]. Quercetin, is one of the best described of this group. It is found in abundance in onions, apples, broccoli and berries. Flavonoid is involved in the scavenging of oxygen derived free radicals [63], and is also a potent hypolipidemic agent [64]. They possess a high antioxidant potential due to their hydroxyl groups and protect efficiently against diseases like arteriosclerosis [65] [66]. Experimental studies showed that flavonoids enhance vaso-relaxant process [67] and prevent platelet related thrombosis [68].

- Saponins: They are naturally occurring surface glycosides. They are synthesized by plants, some bacteria and lower marine animals [69]. Saponins derived its name from its ability to form soap like foams in aqueous solutions [70]. The structure of saponin consists of a sugar moiety (glucose, galactose, glucuronic acid, xylose, rhamnose or methyl pentose) which is linked via glycosidic linkage and attached to a hydrophobic aglycone (sapogenin) which may be a triterpenoid or a steroid. Two types of saponin have been identified, the triterpenoid and steroid saponins. The steroid saponins are often found in medicinal plants, oats, capsicum, pepper, aubergine and ginseng. Triterpenenoid saponins can be found in many legumes such as soyabeans, beans, peas, lurcene etc. [71]. Both triterpene and steroidal aglycones have a number of different substituents $\left(\mathrm{H}, \mathrm{COOH}\right.$, and $\left.\mathrm{CH}_{3}\right)$. The sugars can be attached to the aglycone either as one, two or three side chains [72]. Saponin exhibits anti-microbial activity and has a lytic effect on erythrocyte membrane [73]. It has also demonstrated hypoglycemic effect [74] and lowering of serum cholesterol levels in animals [75] [76]. Saponins reduce protein digestibility by the formation of sparingly digestible saponin-protein complexes [77]. Endogenous saponins affects the chymotrypsic hydrolysis of soyabean protein, particularly glycinin [78]. Saponins have been reported to be highly toxic to fish because of their damaging effect on the respiratory epithelia [79]. They are also considered to be the active compo- 
nents of many traditionally used fish poisons, like mahua oil cake [80]. Quin and $\mathrm{Xu}$ found that the butanol extract of Mussaenda pubescens was capable of terminating pregnancy in rats [81]. Saponins exhibit abortifacient, anti-zygotic and anti-implantation properties and are often used as contraceptives in many places [73]. Saponin isolates have also shown specific inhibition on the growth of cancer cell in vitro [82], and anti-oxidant properties [83].

- Alkaloids: Alkaloids are a group of complex nitrogen containing compounds derived from microbes, marine organisms and plants. Alkaloids are structurally diverse with over 12,000 structures elucidated from plants [84] [85] [86]. Well known alkaloid compounds include-purine alkaloids (caffeine, theobromine), tropane alkaloids (cocaine, scopolamine), benzyl isoquinoline alkaloids (berberine, morphine) and monoterpenol indole alkaloids (vinblastine, ajmaline). Alkaloids are classified based on their primary metabolite purine alkaloids that are produced from adenine or guanine. Tropane alkaloids (TA) are produced from ornithine, Isoquinoline alakloids (IQA) are produced from tyrosine, Monoterpenoid indole alkaloids (MIA) derived from tryptophan [87]. They are used widely as anti-cancer agents, anti-malarials and analgesic and in the treatment of Parkinson's hypertension and central nervous system disorders [88].

- Tannins: Tannins (tannic acids) are naturally occurring complex chemicals found in plants. They are of two distinct types: Hydrolysable tannins (polyesters of gallic acid) and Condensed tannins [89]. Hydrolysable tannins are gallic acid and egallic acid that consist of polyols such as sugars and phenolics such as Catechin. P-Penta-O-galloyl-D-glucose is tannic acid and is the model compound for this group of tannins. Hydrolysable tannins are further classified according to the products of hydrolysis; gallotannins yield gallic acid and glucose, and ellagitannins yield ellagic acid and glucose [90]. Condensed tannins include Pro-anthocyanidins that are polymers of flavan 3-ols linked through an interflavan carbon bond. Thus more accurate definitions are needed and the most unambiguous tannin definition is based on their chemical structures. In addition to their fundamental activities, i.e., binding to proteins, large molecular compounds and metallic ions, and also exhibiting antioxidant activities. Some structure-specific activities were found for the condensation of dehydroellagitannins with co-existing compounds under mild conditions, and the host-mediated antitumor actions of ellagitannin oligomers [91] [92].

- Cardiac glycosides: The aglycone part of cardiac glycosides is a tetracyclic steroid with an attached unsaturated lactone ring that may have 5 or 6 members. Cardiac glycosides are classified into two groups according to the lactone ring: the C-23 cardenolides with an $\alpha, \beta$-unsaturated $\delta$ - $\gamma$-lactone (butenolide) and the $\mathrm{C}$-24 bufadienolides with a di-unsaturated $\gamma$-lactone (pentadienolide). Majority of saccharides found in cardiac glycosides are highly specific. They are 2,6dideoxyhexoses, such as $\mathrm{D}$-digitoxose, $\mathrm{L}$-oleandrose or $\mathrm{D}$-diginose. 
Cardiac glycosides such as digitoxin from Digitalis have been used as drugs for the treatment of cardiac insufficiency. Apart from that cardiac glycosides are also being used in the treatment of cancer. These compounds typically inhibit cancer cell proliferation and growth and activate tumor-specific immune responses. They are ligands for $\mathrm{Na} / \mathrm{K}$-ATPase, which is a promising drug target in cancer [93] [94] [95].

\subsection{Traditional Medicine and Anti-Cancer Properties}

Cancer is a major global health burden with approx 10.9 million new cases, 6.7 million deaths and 24.6 million surviving patients all around the world since 2002 [96] [97]. Since 1990, there has been $22 \%$ increase in cancer cases and mortality, with most frequent cancers being lung, breast, colorectal, stomach, oral, skin and ovary [98] [99].

Thus it has become necessary to investigate new strategies to prevent and treat cancer. Medicinal plant derivatives and secondary metabolites have played important roles in the treatment of cancer. The National Cancer Institute has collected about 35,000 plant samples from 20 countries and screened out 114,000 extracts for anti-cancer activity [97]. Of all the available anti-cancer drugs during 1940-2002, 40\% were natural products or their derivatives, another $8 \%$ were natural products mimics [100]. Anti-cancer agents from medicinal plants that are currently in use can be grouped into four classes of compounds: Vinca (or Catharanthus) alkaloids, epipodophyllotoxins, taxanes and camptothecins. Vinblastine and vincristine are isolated from Catharanthus roseus and have been clinically used for over 40 years [101], for a variety of cancers including leukemia, lymphomas, advanced testicular cancer, breast and lung cancers and Kaposi's sarcoma [100]. The mechanism of action of vinca alkaloids and several other semi-synthetic derivatives is blocking mitosis with metaphase arrest, which occurs by binding specifically to tubulin resulting in its depolymerization [102]. Podophyllotoxin isolated from resin of Podophyllum peltatum was found to be too toxic to host so its derivatives were made [103]. Etoposide and teniposide are two semi-synthetic derivatives of epipodophyllotoxin and are used in the treatment of lymphomas, bronchial and testicular cancers [100] [102] [103] [104]. The epipodophyllotoxin binds tubulin, causing DNA strand breaks during the G2 phase of the cell cycle by irreversibly inhibiting DNA topoisomerase II [103]. Paclitaxel was isolated from Taxus brevifolia and is significantly active against ovarian cancer, advanced breast cancer, small and non-small cell lung cancer [105] [106] [107]. The taxanes including Paclitaxel and its derivatives act by binding to tubulin without allowing depolymerization or interfering with tubulin assembly [108] [109]. The cells show defects in mitotic spindle assembly, chromosome segregation, and cell division and are unable to achieve metaphase spindle configuration. The spindle inhibition role is attributed to suppress the microtubules dynamics and occurs at lower concentrations than those needed to block mitosis. Camptothecin isolated from Camptotheca acuminata, originally showed unacceptable myelosuppression [105]-[112]. However, interest in 
Camptothecin revived when it was found to be selective inhibitor of topoisomerase I, involved in cleavage and reassembly of DNA [112]. The effect causes damage in DNA and apoptosis of the cancer cells due to the conversion of single-strand break into double-strand break resulting from the collision of the replication fork at cleavable complex. Together taxanes and camptothecins account for approximately one third of the global anti-cancer market in 2002. Numerous derivatives of all four compound classes are currently in clinical use. There are more than 270,000 plants existing on this planet waiting to be explored [113]. Here we have also mentioned some of plant active principles and there activity on different cancer cell lines with structural formulas in Table 1.

\subsection{TM/CAM Safety Features}

Secondary metabolites are in great demand due to their inexpensiveness, better cultural acceptability, and better compatibility with minimal side effects [159]. They are relatively safe because they are derived from natural compounds rendering less toxicity [160]. They are also potential source of chemical constituents with anti-tumor and cytotoxic activities [161] [162]. They have anti-cancerous potential due to occurrence of natural antioxidants acting as reducing agents, free radical scavengers and quenchers of singlet oxygen. Greater part of their antioxidant action is due to bioactive compounds viz flavones, isoflavones, flavonoids, anthocyanins, coumarins, lignans, catechins and isocatechins that help in reducing or minimizing the toxic side effect of conventional treatments [12] [163].

\section{Limitations}

The traditional medicine takes long time to act and gives response towards the disease in slow manner. The active principles of medicinal plants are also allergic sometimes. Herbal medicines are not effective in case of cancer, chronic diseases, and sudden illness and auto immune diseases. Herbal medicines isolation and characterization for the drug discovery have numerous limitations, if incorrect identification is done it can lead to serious side effects. It is generally observed that herbal medicines are not properly regulated because it has so many secondary metabolites such that it does not show quality assurance. While using active plant derived secondary metabolites having obstacles toward the cancer and other chronic diseases: Plant active secondary metabolites may vary regions to region according to geographical with lack of definite safety consideration behalf of specificity and sensitivity because its highly complex active personalized ingredient for specific formulations in addition one of the major drawbacks of the plant metabolite is lack of defined molecular targets.

\section{Future Prospects and Applications}

In the future, each patient should have their own unique chemotherapy protocol, which improves the therapeutic quality by selecting and prescribing 
Table 1. In vitro effects of various bioactive compounds: mechanism, structure on various cancer cell line.

\begin{tabular}{|c|c|c|c|c|c|}
\hline $\begin{array}{l}\text { Cancer } \\
\text { type }\end{array}$ & $\begin{array}{r}\text { Active } \\
\text { Stru }\end{array}$ & $\begin{array}{l}\text { ound and } \\
\text { ormula }\end{array}$ & Mechanism of action & Cell lines & References \\
\hline \multirow{4}{*}{$\begin{array}{l}\text { Breast } \\
\text { cancer }\end{array}$} & FLAVONOIDS & $\begin{array}{c}\text { Flavanones } \\
\left(\mathrm{C}_{15} \mathrm{H}_{10} \mathrm{O}_{3}\right) \\
\text { Daidzein } \\
\left(\mathrm{C}_{15} \mathrm{H}_{10} \mathrm{O}_{4}\right) \\
\text { Genistein } \\
\left(\mathrm{C}_{15} \mathrm{H}_{10} \mathrm{O}_{5}\right) \\
\text { Quercetin } \\
\left(\mathrm{C}_{15} \mathrm{H}_{10} \mathrm{O}_{7}\right) \\
\text { Luteolin } \\
\left(\mathrm{C}_{15} \mathrm{H}_{10} \mathrm{O}_{6}\right)\end{array}$ & $\begin{array}{l}\text { Inhibition of the Epidermal Growth } \\
\text { Factor (EGF) receptor in the } \\
\text { sub-micromolar range by competing } \\
\text { with ATP for its binding site. }\end{array}$ & MCF-7 & [114] [115] \\
\hline & ALKALOIDS & $\begin{array}{c}\text { Vinblastin } \\
\left(\mathrm{C}_{46} \mathrm{H}_{58} \mathrm{~N}_{4} \mathrm{O}_{9}\right) \\
\text { Vincristine } \\
\left(\mathrm{C}_{46} \mathrm{H}_{56} \mathrm{~N}_{4} \mathrm{O}_{10}\right) \\
\text { Taxol } \\
\left(\mathrm{C}_{47} \mathrm{H}_{51} \mathrm{NO}_{14}\right) \\
\\
\mathrm{Noscapine} \\
\left(\mathrm{C}_{22} \mathrm{H}_{23} \mathrm{NO}_{7}\right)\end{array}$ & $\begin{array}{l}\text { Cellular microtubules stabilization by } \\
\text { binding to } \beta \text {-tubulin subunit, causing } \\
\text { interference in their normal breakdown } \\
\text { during cell division, with resultant } \\
\text { stabilization of the polymer through } \\
\text { protection from disassembly. }\end{array}$ & $\begin{array}{c}\text { MDA-MB-231 } \\
\text { MCF-7 }\end{array}$ & $\begin{array}{l}{[116][117]} \\
{[118][119]}\end{array}$ \\
\hline & SAPONINS & $\begin{array}{c}\text { Saponins } \\
\left(\mathrm{C}_{44} \mathrm{H}_{70} \mathrm{O}_{17}\right) \\
\text { Maplexins A } \\
\left(\mathrm{C}_{13} \mathrm{H}_{16} \mathrm{O}_{9}\right)\end{array}$ & $\begin{array}{l}\text { Induce cell cycle (G1) arrest, } \\
\text { Apoptotic and anti-proliferative activity. }\end{array}$ & $\begin{array}{l}\text { MDA-MB-453, } \\
\text { MCF-7 } \\
\text { MCF-7, } \\
\text { MCF7/HER2, } \\
\text { JIMT-1 }\end{array}$ & [120] [121] \\
\hline & $\begin{array}{c}\text { CARDIAC } \\
\text { GLYCOSIDES }\end{array}$ & $\begin{array}{c}\text { Digitoxin } \\
\left(\mathrm{C}_{41} \mathrm{H}_{64} \mathrm{O}_{13}\right) \\
\text { Digoxin } \\
\left(\mathrm{C}_{41} \mathrm{H}_{64} \mathrm{O}_{14}\right) \\
\text { Proscillaridin } \\
\left(\mathrm{C}_{30} \mathrm{H}_{42} \mathrm{O}_{8}\right) \\
\text { Ouabain } \\
\left(\mathrm{C}_{29} \mathrm{H}_{44} \mathrm{O}_{12}\right)\end{array}$ & Inhibition of Topoisomerases I and II. & $\begin{array}{c}\text { MCF-7, } \\
\text { MDA-MD-435 }\end{array}$ & [124] [125] \\
\hline Leukemia & FLAVONOIDS & $\begin{array}{c}\text { Sophoranone } \\
\left(\mathrm{C}_{30} \mathrm{H}_{36} \mathrm{O}_{4}\right) \\
\text { Genistein } \\
\left(\mathrm{C}_{15} \mathrm{H}_{10} \mathrm{O}_{5}\right) \\
\text { Apigenin } \\
\left(\mathrm{C}_{15} \mathrm{H}_{10} \mathrm{O}_{5}\right) \\
\text { Quercetin } \\
\left(\mathrm{C}_{15} \mathrm{H}_{10} \mathrm{O}_{7}\right) \\
\\
\text { Myricetin } \\
\left(\mathrm{C}_{15} \mathrm{H}_{10} \mathrm{O}_{8}\right) \\
\\
\text { Chalcones } \\
\left(\mathrm{C}_{15} \mathrm{H}_{12} \mathrm{O}\right)\end{array}$ & $\begin{array}{l}\text { Inhibition of cell growth } \\
\text { Induction of apoptosis. Induction of } \\
\text { phase II metabolizing enzymes such as } \\
\text { glutathione-S-transferase, quinine } \\
\text { reductase, and } \\
\text { UDP-glucuronyltransferase resulting } \\
\text { in detoxification and elimination of } \\
\text { carcinogens from the body. }\end{array}$ & $\begin{array}{l}\text { U937 } \\
\text { cells,HL-60, } \\
\text { K562, Jurkat }\end{array}$ & $\begin{array}{l}{[126][127]} \\
{[128][129]}\end{array}$ \\
\hline
\end{tabular}




\section{Continued}

\begin{tabular}{|c|c|c|c|c|c|}
\hline & ALKALOIDS & $\begin{array}{c}\text { Vinblastin } \\
\left(\mathrm{C}_{46} \mathrm{H}_{58} \mathrm{~N}_{4} \mathrm{O}_{9}\right) \\
\text { Vincristine } \\
\left(\mathrm{C}_{46} \mathrm{H}_{56} \mathrm{~N}_{4} \mathrm{O}_{10}\right) \\
\text { Cryptolepine } \\
\left(\mathrm{C}_{16} \mathrm{H}_{12} \mathrm{~N}_{2}\right)\end{array}$ & $\begin{array}{l}\text { Inhibition of cellular proliferation by } \\
\text { altering the dynamics of tubulin addition } \\
\text { and loss at the ends of mitotic spindle } \\
\text { microtubules. }\end{array}$ & $\begin{array}{l}\text { CCRF-CEM } \\
\text { CEM/VM-1 }\end{array}$ & $\begin{array}{l}{[119][130]} \\
{[131][132]}\end{array}$ \\
\hline & SAPONINS & $\begin{array}{l}\text { Saponin } \\
\left(\mathrm{C}_{44} \mathrm{H}_{70} \mathrm{O}_{17}\right)\end{array}$ & $\begin{array}{l}\text { Causes cytotoxicity and apoptosis } \\
\text { in tumor cells. }\end{array}$ & Jurkat, HL 60 & {$[120][133]$} \\
\hline & $\begin{array}{c}\text { CARDIAC } \\
\text { GLYCOSIDES }\end{array}$ & $\begin{array}{c}\text { Bufalin } \\
\left(\mathrm{C}_{24} \mathrm{H}_{34} \mathrm{O}_{4}\right) \\
\text { Oleandrin } \\
\left(\mathrm{C}_{32} \mathrm{H}_{48} \mathrm{O}_{9}\right) \\
\text { Digitoxin } \\
\left(\mathrm{C}_{41} \mathrm{H}_{64} \mathrm{O}_{13}\right) \\
\text { Proscillaridin A } \\
\left(\mathrm{C}_{30} \mathrm{H}_{42} \mathrm{O}_{8}\right) \\
\text { Ouabain } \\
\left(\mathrm{C}_{29} \mathrm{H}_{44} \mathrm{O}_{12}\right)\end{array}$ & $\begin{array}{l}\text { Inhibition of topoisomerases I and II, } \\
\text { Increased activation of MAPKs, Down } \\
\text { regulation of cyclin A, Bcl- } 2 \text { and BclxL, } \\
\text { Increased expression of p } 21 \text { and Bax. }\end{array}$ & $\begin{array}{l}\text { HL60, U-937, } \\
\text { CCRF-CEM, } \\
\text { CEM-VM-1 }\end{array}$ & $\begin{array}{c}{[125][134]} \\
{[135]}\end{array}$ \\
\hline Stomach & FLAVONOIDS & $\begin{array}{l}\text { Sophoranone } \\
\left(\mathrm{C}_{30} \mathrm{H}_{36} \mathrm{O}_{4}\right)\end{array}$ & $\begin{array}{l}\text { Inhibition of cellular growth and } \\
\text { induction of apoptosis. Inhibition, } \\
\text { reversion or retardation of cellular } \\
\text { hyperproliferation. }\end{array}$ & MKN7 cells & [136] \\
\hline & SAPONINS & $\begin{array}{l}\text { Saponins } \\
\left(\mathrm{C}_{44} \mathrm{H}_{70} \mathrm{O}_{17}\right)\end{array}$ & Cytotoxic effects on tumor cells. & SGC-7901 & [137] \\
\hline \multirow{3}{*}{$\begin{array}{l}\text { Colon } \\
\text { Cancer }\end{array}$} & FLAVONOIDS & $\begin{array}{c}\text { Flavone } \\
\left(\mathrm{C}_{15} \mathrm{H}_{10} \mathrm{O}_{2}\right) \\
\text { Quercetin } \\
\left(\mathrm{C}_{15} \mathrm{H}_{10} \mathrm{O}_{7}\right) \\
\text { Genistein } \\
\left(\mathrm{C}_{15} \mathrm{H}_{10} \mathrm{O}_{5}\right) \\
\text { Anthocyanin } \\
\left(\mathrm{C}_{15} \mathrm{H}_{11} \mathrm{O}+\right)\end{array}$ & $\begin{array}{l}\text { Inhibition of cellular proliferation and } \\
\text { cytotoxicity, Perturbations in cell cycle } \\
\text { progression. Checkpoints at both G1/S } \\
\text { and G2/M of the cell cycle. }\end{array}$ & $\begin{array}{c}\text { Caco-2 and } \\
\text { HT-29 }\end{array}$ & $\begin{array}{c}\text { [138] [139] } \\
{[140]}\end{array}$ \\
\hline & ALKALOIDS & $\begin{array}{c}\text { Camptothecin } \\
\left(\mathrm{C}_{20} \mathrm{H}_{16} \mathrm{~N}_{2} \mathrm{O}_{4}\right) \\
\text { Topotecan } \\
\left(\mathrm{C}_{23} \mathrm{H}_{23} \mathrm{~N}_{3} \mathrm{O}_{5}\right) \\
\text { Irinotecan } \\
\left(\mathrm{C}_{33} \mathrm{H}_{38} \mathrm{~N}_{4} \mathrm{O}_{6}\right) \\
\text { Arctigenin } \\
\left(\mathrm{C}_{21} \mathrm{H}_{24} \mathrm{O}_{6}\right)\end{array}$ & $\begin{array}{l}\text { It involves binding topoisomerase } \\
\text { I-DNA covalent complex, forming a } \\
\text { ternary complex that gets stabilized and } \\
\text { DNA is prevented from religation during } \\
\text { replication, that leads to damage in DNA } \\
\text { and apoptosis of the cancer cells as } \\
\text { single-strand break converts into } \\
\text { double-strand break }\end{array}$ & $\mathrm{CaCo} 2, \mathrm{~T} 84$ & $\begin{array}{l}{[141][142]} \\
{[143][144]}\end{array}$ \\
\hline & SAPONINS & $\begin{array}{l}\text { Saponins } \\
\left(\mathrm{C}_{44} \mathrm{H}_{70} \mathrm{O}_{17}\right)\end{array}$ & $\begin{array}{l}\text { Inhibits cell proliferation through } \\
\text { accumulation in } \mathrm{S} \text { phase and } \mathrm{G} 2 / \mathrm{M} \\
\text { arrest, with concomitant suppression of } \\
\text { p21 expression and inhibition of } \\
\text { cyclin-dependent kinase activity. }\end{array}$ & HT-29, C26 & [145] [146] \\
\hline
\end{tabular}




\section{Continued}

\begin{tabular}{|c|c|c|c|c|c|}
\hline & TANNINS & $\begin{array}{l}\text { Maplexins A -I } \\
\quad\left(\mathrm{C}_{13} \mathrm{H}_{16} \mathrm{O}_{9}\right)\end{array}$ & $\begin{array}{l}\text { Down-regulation of cyclins A and B1 } \\
\text { and upregulating of cyclin E, cell-cycle } \\
\text { arrest in S phase, induction of apoptosis } \\
\text { via intrinsic pathway (FAS-independent, } \\
\text { caspase 8-independent) through bcl-XL } \\
\text { down-regulation with mitochondrial } \\
\text { release of cytochrome c into the cytosol, } \\
\text { activation of initiator caspase } 9 \text { and } \\
\text { effector caspase-3. }\end{array}$ & $\begin{array}{l}\text { HCT-116, } \\
\text { Caco- } 2, \\
\text { CCD-112CoN }\end{array}$ & [147] [148] \\
\hline \multirow[t]{2}{*}{$\begin{array}{c}\text { Oral } \\
\text { Cancer }\end{array}$} & FLAVONOIDS & $\begin{array}{c}\text { Flavanones } \\
\left(\mathrm{C}_{15} \mathrm{H}_{10} \mathrm{O}_{3}\right) \\
\text { Isoflavonone } \\
\left(\mathrm{C}_{15} \mathrm{H}_{12} \mathrm{O}_{2}\right) \\
\text { EGC } \\
\left(\mathrm{C}_{15} \mathrm{H}_{14} \mathrm{O}_{7}\right) \\
\text { Chalcones } \\
\left(\mathrm{C}_{15} \mathrm{H}_{12} \mathrm{O}\right) \\
\\
\text { EGCG } \\
\left(\mathrm{C}_{22} \mathrm{H}_{18} \mathrm{O}_{11}\right) \\
\\
\mathrm{Curcumin} \\
\left(\mathrm{C}_{21} \mathrm{H}_{20} \mathrm{O}_{6}\right) \\
\\
\text { Genistein } \\
\left(\mathrm{C}_{15} \mathrm{H}_{10} \mathrm{O}_{5}\right) \\
\text { Quercetin, } \\
\left(\mathrm{C}_{15} \mathrm{H}_{10} \mathrm{O}_{7}\right) \\
\text { Cisplatin } \\
\left(\mathrm{C}_{20} \mathrm{H}_{28} \mathrm{~N}_{12} \mathrm{O}_{9} \mathrm{PPt}+\right)\end{array}$ & $\begin{array}{l}\text { Interaction with phase I metabolizing } \\
\text { enzymes (e.g., cytochrome P450), } \\
\text { which metabolically inactivate a } \\
\text { large number of procarcinogens. }\end{array}$ & $\begin{array}{l}\text { HSC-2, HSG, } \\
\text { SCC- } 25\end{array}$ & $\begin{array}{l}{[149][150]} \\
{[151][152]} \\
\quad[153]\end{array}$ \\
\hline & TANNINS & $\begin{array}{l}\text { Total Pomegranate } \\
\text { Tannin (TPT) extract }\end{array}$ & Anti-proliferative activity & $\mathrm{KB}, \mathrm{CAL} 27$ & [147] \\
\hline \multirow[b]{2}{*}{$\begin{array}{l}\text { Lung } \\
\text { Cancer }\end{array}$} & FLAVONOID & $\begin{array}{c}\text { Flavone } \\
\left(\mathrm{C}_{15} \mathrm{H}_{10} \mathrm{O}_{2}\right) \\
\text { Quercetin } \\
\left(\mathrm{C}_{15} \mathrm{H}_{10} \mathrm{O}_{7}\right)\end{array}$ & Inhibition of tyrosine kinases. & $\begin{array}{l}\text { SK-LU1, SW900, } \\
\text { H441, H661, } \\
\text { haGo-K-1, A549 }\end{array}$ & [154] [155] \\
\hline & ALKALOID & $\begin{array}{c}\text { Taxol } \\
\left(\mathrm{C}_{47} \mathrm{H}_{51} \mathrm{NO}_{14}\right) \\
\text { Camptothecin } \\
\left(\mathrm{C}_{20} \mathrm{H}_{16} \mathrm{~N}_{2} \mathrm{O}_{4}\right)\end{array}$ & $\begin{array}{l}\text { Inhibition of cellular proliferation by } \\
\text { altering the dynamics of tubulin } \\
\text { addition and loss at the ends of } \\
\text { mitotic spindle microtubules. }\end{array}$ & A549 & $\begin{array}{l}{[117][119]} \\
{[141][156]} \\
{[157]}\end{array}$ \\
\hline
\end{tabular}


Sanguinarine

$\left(\mathrm{C}_{20} \mathrm{H}_{14} \mathrm{NO}_{4}\right)$

Chelerythrine

$\left(\mathrm{C}_{21} \mathrm{H}_{18} \mathrm{NO}_{4}\right)$

Chelidonine

$\left(\mathrm{C}_{20} \mathrm{H}_{19} \mathrm{NO}_{5}\right)$

Noscapine

$\left(\mathrm{C}_{22} \mathrm{H}_{23} \mathrm{NO}_{7}\right)$

\begin{tabular}{|c|c|c|c|c|}
\hline SAPONINS & $\begin{array}{l}\text { Saponins } \\
\left(\mathrm{C}_{44} \mathrm{H}_{70} \mathrm{O}_{17}\right)\end{array}$ & Apoptosis, cytotoxic activity. & A549, NCI-H727 & [133] [137] \\
\hline \multirow{3}{*}{$\begin{array}{c}\text { CARDIAC } \\
\text { GLYCOSIDES }\end{array}$} & $\begin{array}{c}\text { Digitoxin } \\
\left(\mathrm{C}_{41} \mathrm{H}_{64} \mathrm{O}_{13}\right)\end{array}$ & \multirow{3}{*}{$\begin{array}{l}\text { Initiates Apo2L/TRAIL apoptosis via } \\
\text { increased expression of death } \\
\text { receptors } 4 \text { and } 5\end{array}$} & \multirow{3}{*}{$\begin{array}{c}\text { NCI-H-358, } \\
\text { Calu1, Sklu1, } \\
\text { NCI-H6, H69AR }\end{array}$} & \multirow{3}{*}[158]{} \\
\hline & $\begin{array}{c}\text { Digoxin } \\
\left(\mathrm{C}_{41} \mathrm{H}_{64} \mathrm{O}_{14}\right)\end{array}$ & & & \\
\hline & $\begin{array}{l}\text { Oleandrin } \\
\left(\mathrm{C}_{22} \mathrm{H}_{23} \mathrm{NO}_{7}\right)\end{array}$ & & & \\
\hline
\end{tabular}

well-matched drugs and avoiding ineffective ones [58] [164]. Applying such individualized chemotherapeutics through a personalized chemotherapy regime will further improve the final outcome [18] [165]. This will be accompanied by the identification and testing of novel, more specific and selective drugs either via synthetic routes or by purifying from herbal sources [166]. Although the novel chemotherapeutic agents will be more and more effective against the tumor cells, their toxicity to normal tissues as well as drug resistance remains the major obstacle for clinical use [167]. Personalized approach using various phytochemical compounds provides a new dimension to the standard cancer therapy for improving its outcome in a complex and complementary way [168] (Figure 1).

Medicinal plants are also important for pharmacological research and drug development, not only when plant constituents are used directly as therapeutic agents, but also as starting materials for the synthesis of drugs or as models for pharmacologically active compounds [169] [170]. Major pharmaceutical companies are presently conducting extensive research on plant materials gathered from various habitats for their potential medicinal value [171]. Rather than using whole plant, scientists identify, isolate, extract and synthesize individual active compounds. Because modern pharmacology looks for one active ingredient and seeks to isolate it to the segregation of all the others, most of the research 

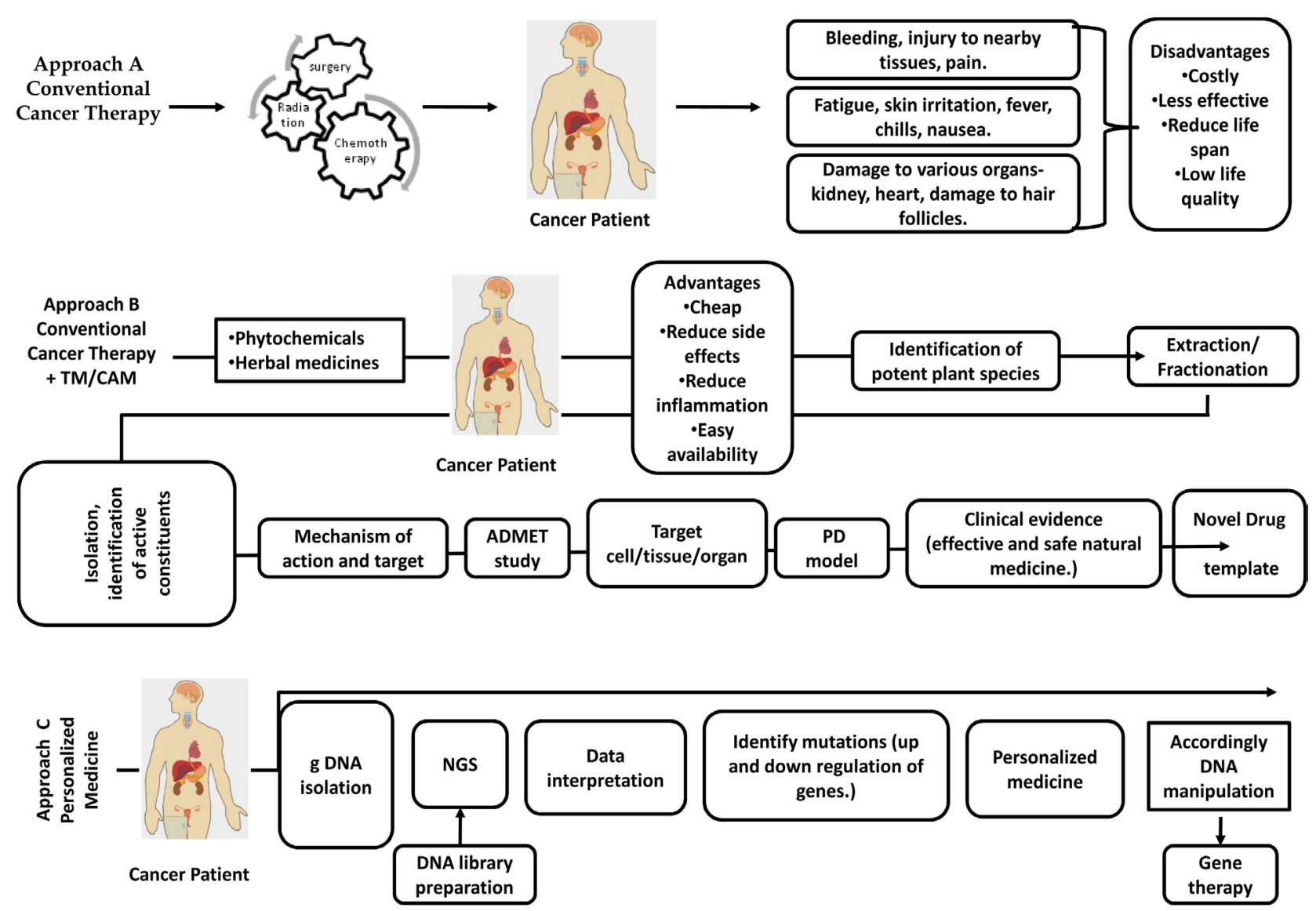

Figure 1. Approach A: Conventional approach used by clinicians commonly including surgery, chemotherapy and radiation therapy; Approach B: Combination therapy including Conventional Cancer therapy and Traditional medicine/complementary alternative medicine (active secondary metabolite with chemo-drugs); Approach C: Future prospects toward the cancer therapy included personalized medicine. ${ }^{\star} \mathrm{ADMET}=$ Absorption, Distribution, Metabolism, Excretion, Toxicity. ${ }^{\star} \mathrm{PK} / \mathrm{PD}=\mathrm{Pharmacoki}-$ netics/Pharmacodynamics. ${ }^{\star} \mathrm{g}$ DNA $=$ genomic DNA. ${ }^{\star} \mathrm{NGS}=$ Next genome sequencing.

focuses on identifying and isolating active ingredients rather than studying the medicinal properties of the whole plant [172]. Despite the remarkable progress in the organic synthetic chemistry, over $25 \%$ of prescribed medicines are derived directly or indirectly from plants which need to be further explored for better clinical intervention in therapeutics [166].

\section{Acknowledgements}

The authors would like to express their deepest gratitude to Department of Biochemistry, AIIMS, Bhopal.

\section{Conflicts of Interest}

The authors declare that there are no conflicts of interest.

\section{References}

[1] Nema, R., Khare, S., Jain, P., Pradhan, A., Gupta, A. and Singh, D. (2013) Natural Products Potential and Scope for Modern Cancer Research. American Journal of 
Plant Sciences, 4, 1270-1277. https://doi.org/10.4236/ajps.2013.46157

[2] Cao, B., Bray, F., Beltrán-Sánchez, H., Ginsburg, O., Soneji, S. and Soerjomataram, I. (2017) Benchmarking Life Expectancy and Cancer Mortality: Global Comparison with Cardiovascular Disease 1981-2010. British Medical Journal, 357, j2765. https://doi.org/10.1136/bmj.j2765

[3] Fan, W., Johnson, K.R. and Miller, M.C. (1998) In Vitro Evaluation of Combination Chemotherapy against Human Tumor Cells (Review). Oncology Reports, 5, 1035-1042. https://doi.org/10.3892/or.5.5.1035

[4] De Vita Jr., V.T. and Chu, E. (2008) A History of Cancer Chemotherapy. Cancer Research, 68, 8643-8653. https://doi.org/10.1158/0008-5472.CAN-07-6611

[5] Kroschinsky, F., Stölzel, F., von Bonin, S., Beutel, G., Kochanek, M., Kiehl, M. and Schellongowski, P. (2017) Intensive Care in Hematological and Oncological Patients (iCHOP) Collaborative Group. New Drugs, New Toxicities: Severe Side Effects of Modern Targeted and Immunotherapy of Cancer and Their Management. Critical Care, 21, 89. https://doi.org/10.1186/s13054-017-1678-1

[6] Bhugwandass, C.S., Pijnenborg, J.M., Pijlman, B. and Ezendam, N.P. (2016) Effect of Chemotherapy on Health-Related Quality of Life among Early-Stage Ovarian Cancer Survivors: A Study from the Population-Based PROFILES Registry. Current Oncology, 23, e556-e562. https://doi.org/10.3747/co.23.3243

[7] Ramirez, L.Y., Huestis, S.E., Yap, T.Y., Zyzanski, S., Drotar, D. and Kodish, E. (2009) Potential Chemotherapy Side Effects: What Do Oncologists Tell Parents? Pediatric Blood \& Cancer, 52, 497-502. https://doi.org/10.1002/pbc.21835

[8] Nurgali, K., Jagoe, R.T. and Abalo, R. (2018) Editorial: Adverse Effects of Cancer Chemotherapy: Anything New to Improve Tolerance and Reduce Sequelae? Frontiers in Pharmacology, 9, 245. https://doi.org/10.3389/fphar.2018.00245

[9] Eyre, H. and Blount, L. (2006) American Cancer Society. Journal of Oncology Practice, 2, 99.

[10] Partridge, A.H., Burstein, H.J. and Winer, E.P. (2001) Side Effects of Chemotherapy and Combined Chemohormonal Therapy in Women with Early-Stage Breast Cancer. JNCI Monographs, 30, 135-42.

https://doi.org/10.1093/oxfordjournals.jncimonographs.a003451

[11] Pearce, A., Haas, M., Viney, R., Pearson, S.A., Haywood, P., Brown, C. and Ward, R. (2017) Incidence and Severity of Self-Reported Chemotherapy Side Effects in Routine Care: A Prospective Cohort Study. PLoS ONE, 12, e0184360. https://doi.org/10.1371/journal.pone.0184360

[12] Muntean, D.M., Sturza, A., Pavel, I.Z. and Duicu, O.M. (2018) Modulation of Cancer Metabolism by Phytochemicals-A Brief Overview. Anti-Cancer Agents in $\mathrm{Me}$ dicinal Chemistry, 18, 684-692.

[13] Talib, W.H. and Mahasneh, A.M. (2010) Antiproliferative Activity of Plant Extracts Used against Cancer in Traditional Medicine. Scientia Pharmaceutica, 78, 33-45. https://doi.org/10.3797/scipharm.0912-11

[14] Sak, K. (2012) Chemotherapy and Dietary Phytochemical Agents. Chemotherapy Research and Practice, 2012, Article ID: 282570. https://doi.org/10.1155/2012/282570

[15] Bayat, M.R., Homayouni, T.S., Baluch, N., Morgatskaya, E., Kumar, S., Das, B. and Yeger, H. (2017) Combination Therapy in Combating Cancer. Oncotarget, 8, 38022-38043. https://doi.org/10.18632/oncotarget.16723

[16] Balachandran, P. and Govindarajan, R. (2005) Cancer-An Ayurvedic Perspective. 
Pharmacological Research, 51, 19-30. https://doi.org/10.1016/j.phrs.2004.04.010

[17] Singh, E., Underwood, J.M., Nattey, C., Babb, C., Sengayi, M. and Kellett, P. (2015) South African National Cancer Registry: Effect of Withheld Data from Private Health Systems on Cancer Incidence Estimates. South African Medical Journal, 105, 107-109. https://doi.org/10.7196/SAMJ.8858

[18] National Cancer Institute (2009).

[19] Singh, R.H. (2002) An Assessment of the Ayurvedic Concept of Cancer and a New Paradigm of Anticancer Treatment in Ayurveda. The Journal of Alternative and Complementary Medicine, 8, 609-614. https://doi.org/10.1089/107555302320825129

[20] Seca, A.M.L. and Pinto, D.C.G.A. (2018) Plant Secondary Metabolites as Anticancer Agents: Successes in Clinical Trials and Therapeutic Application. International Journal of Molecular Sciences, 19, 263. https://doi.org/10.3390/ijms19010263

[21] Petrovska, B.B. (2012) Historical Review of Medicinal Plants' Usage. Pharmacognosy Reviews, 6, 1-5. https://doi.org/10.4103/0973-7847.95849

[22] Sahoo, S. and Brijesh, S. (2019) Pharmacogenomic Assessment of Herbal Drugs in Affective Disorders. Biomedicine \& Pharmacotherapy, 109, 1148-1162. https://doi.org/10.1016/j.biopha.2018.10.135

[23] Pan, S.Y., Litscher, G., Gao, S.H., Zhou, S.F., Yu, Z.L., Chen, H.Q., Zhang, S.F., Tang, M.K., Sun, J.N. and Ko, K.M. (2014) Historical Perspective of Traditional Indigenous Medical Practices: The Current Renaissance and Conservation of Herbal Resources. Evidence-Based Complementary and Alternative Medicine, 2014, Article ID: 525340. https://doi.org/10.1155/2014/525340

[24] Munos, B. (2009) Lessons from 60 Years of Pharmaceutical Innovation. Nature Reviews Drug Discovery, 8, 959-968. https://doi.org/10.1038/nrd2961

[25] Humber, J.M. (2002) The Role of Complementary and Alternative Medicine: Accommodating Pluralism. Journal of the American Medical Association, 288, 1655-1656.

[26] Pandey, M.M., Rastogi, S. and Rawat, A.K. (2013) Indian Traditional Ayurvedic System of Medicine and Nutritional Supplementation. Evidence-Based Complementary and Alternative Medicine, 2013, Article ID: 376327. https://doi.org/10.1155/2013/376327

[27] Cragg, G.M. and Newman, D.J. (2013) Natural Products: A Continuing Source of Novel Drug Leads. Biochimica et Biophysica Acta (BBA)-General Subjects, 1830, 3670-3695. https://doi.org/10.1016/j.bbagen.2013.02.008

[28] Gurib-Fakim, A. (2006) Medicinal Plants: Traditions of Yesterday and Drugs of Tomorrow. Molecular Aspects of Medicine, 27, 1-93. https://doi.org/10.1016/j.mam.2005.07.008

[29] Saklani, A. and Kutty, S.K. (2008) Plant-Derived Compounds in Clinical Trials. Drug Discovery Today, 13, 161-71. https://doi.org/10.1016/j.drudis.2007.10.010

[30] Enioutina, E.Y., Salis, E.R., Job, K.M., Gubarev, M.I., Krepkova, L.V. and Sherwin, C.M. (2017) Herbal Medicines: Challenges in the Modern World. Part 5. Status and Current Directions of Complementary and Alternative Herbal Medicine Worldwide. Expert Review of Clinical Pharmacology, 10, 327-338. https://doi.org/10.1080/17512433.2017.1268917

[31] Media Centre (2013) Traditional Medicine.

[32] Falodun, A. (2010) Herbal Medicine in Africa-Distribution, Standardization and Prospects. Research Journal of Phytochemistry, 4, 154-161. 
https://doi.org/10.3923/riphyto.2010.154.161

[33] Farnsworth, N.R., Akerele, O., Bingel, A.S., Soejarto, D.D. and Guo, Z. (1985) Medicinal Plants in Therapy. Bulletin of the World Health Organization, 63, 965-981.

[34] Salehi, B., Zucca, P., Sharifi-Rad, M., Pezzani, R., Rajabi, S., Setzer, W.N., Varoni, E.M., Iriti, M., Kobarfard, F. and Sharifi-Rad, J. (2018) Phytotherapeutics in Cancer Invasion and Metastasis. Phytotherapy Research, 32, 1425-1449. https://doi.org/10.1002/ptr.6087

[35] Saad, B., Azaizeh, H. and Said, O. (2005) Tradition and Perspectives of Arab Herbal Medicine: A Review. Evidence-Based Complementary and Alternative Medicine, 2, 475-479. https://doi.org/10.1093/ecam/neh133

[36] Pohl, F., Kong, T. and Lin, P. (2018) The Potential Use of Plant Natural Products and Plant Extracts with Antioxidant Properties for the Prevention/Treatment of Neurodegenerative Diseases: In Vitro, In Vivo and Clinical Trials. Molecules, 23, 3283. https://doi.org/10.3390/molecules 23123283

[37] Niazian, M. (2019) Application of Genetics and Biotechnology for Improving Medicinal Plants. Planta, 249, 953-973. https://doi.org/10.1007/s00425-019-03099-1

[38] Ramalingum, N. and Mahomoodally, M.F. (2014) The Therapeutic Potential of Medicinal Foods. Advances in Pharmacological Sciences, 2014, Article ID: 354264. https://doi.org/10.1155/2014/354264

[39] Kuruvilla, K. (2010) Indian Contribution to Behavior Therapy. Indian Journal of Psychiatry, 52, S371-S377. https://doi.org/10.4103/0019-5545.69271

[40] Alves-Silva, J.M., Romane, A., Efferth, T. and Salgueiro, L. (2017) North African Medicinal Plants Traditionally Used in Cancer Therapy. Frontiers in Pharmacology, 8, 383. https://doi.org/10.3389/fphar.2017.00383

[41] Tariq, A., Sadia, S., Pan, K., Ullah, I., Mussarat, S., Sun, F., Abiodun, O.O., Batbaatar, A., Li, Z., Song, D., Xiong, Q., Ullah, R., Khan, S., Basnet, B.B., Kumar, B., Islam, R. and Adnan, M. (2017) A Systematic Review on Ethnomedicines of Anti-Cancer Plants. Phytotherapy Research, 31, 202-264.

https://doi.org/10.1002/ptr.5751

[42] Diorio, C., Salena, K., Ladas, E.J., Lam, C.G., Afungcwhi, G.M., Njuguna, F. and Marjerrison, S. (2017) Traditional and Complementary Medicine Used with Curative Intent in Childhood Cancer: A Systematic Review. Pediatric Blood \& Cancer, 64, e26501. https://doi.org/10.1002/pbc.26501

[43] Ma, L., Wang, B., Long, Y. and Li, H. (2017) Effect of Traditional Chinese Medicine Combined with Western Therapy on Primary Hepatic Carcinoma: A Systematic Review with Meta-Analysis. Frontiers of Medicine, 11, 191-202. https://doi.org/10.1007/s11684-017-0512-0

[44] Mishra, B.B. and Tiwari, V.K. (2011) Natural Products: An Evolving Role in Future Drug Discovery. European Journal of Medicinal Chemistry, 46, 4769-807. https://doi.org/10.1016/j.ejmech.2011.07.057

[45] Gali-Muhtasib, H., Hmadi, R., Kareh, M., Tohme, R. and Darwiche, N. (2015) Cell Death Mechanisms of Plant-Derived Anticancer Drugs: Beyond Apoptosis. Apoptosis, 20, 1531-1562. https://doi.org/10.1007/s10495-015-1169-2

[46] Khalid, E.B., Ayman, E.E., Rahman, H., Abdelkarim, G. and Najda, A. (2016) Natural Products against Cancer Angiogenesis. Tumor Biology, 37, 14513-14536. https://doi.org/10.1007/s13277-016-5364-8

[47] WHO (2002) Monographs on Selected Medicinal Plants, Vol. 2. World Health Organization, Geneva. 
[48] Nobili, S., Lippi, D., Witort, E., Donnini, M., Bausi, L., Mini, E. and Capaccioli, S. (2009) Natural Compounds for Cancer Treatment and Prevention. Pharmacological Research, 59, 365-378. https://doi.org/10.1016/j.phrs.2009.01.017

[49] Yin, S.Y., Wei, W.C., Jian, F.Y., Yang, N.S. (2013) Therapeutic Applications of Herbal Medicines for Cancer Patients. Evidence-Based Complementary and Alternative Medicine, 2013, Article ID: 302426. https://doi.org/10.1155/2013/302426

[50] Mathur, S. and Hoskins, C. (2017) Drug development: Lessons from Nature. Biomedical Reports, 6, 612-614. https://doi.org/10.3892/br.2017.909

[51] Newman, D.J. and Cragg, G.M. (2016) Natural Products as Sources of New Drugs from 1981 to 2014. Journal of Natural Products, 79, 629-661. https://doi.org/10.1021/acs.jnatprod.5b01055

[52] Sertel, S., Fu, Y., Zu, Y., Rebacz, B., Konkimalla, B., Plinkert, P.K., Krämer, A., Gertsch, J. and Efferth, T. (2011) Molecular Docking and Pharmacogenomics of Vinca Alkaloids and Their Monomeric Precursors, Vindoline and Catharanthine. Biochemical Pharmacology, 81, 723-735. https://doi.org/10.1016/j.bcp.2010.12.026

[53] Weaver, B.A. (2014) How Taxol/Paclitaxel Kills Cancer Cells. Molecular Biology of the Cell, 25, 2677-2681. https://doi.org/10.1091/mbc.e14-04-0916

[54] Bernabeu, E., Cagel, M., Lagomarsino, E., Moretton, M. and Chiappetta, D.A. (2017) Paclitaxel: What Has Been Done and the Challenges Remain Ahead. International Journal of Pharmaceutics, 526, 474-495. https://doi.org/10.1016/j.ijpharm.2017.05.016

[55] Kantarjian, H.M., O’Brien, S. and Cortes, J. (2013) Homoharringtonine/Omacetaxine Mepesuccinate: The Long and Winding Road to Food and Drug Administration Approval. Clinical Lymphoma, Myeloma and Leukemia, 13, 530-533. https://doi.org/10.1016/j.clml.2013.03.017

[56] Kocaadam, B. and Şanlier, N. (2017) Curcumin, an Active Component of Turmeric (Curcuma longa), and Its Effects on Health. Critical Reviews in Food Science and Nutrition, 57, 2889-2895. https://doi.org/10.1080/10408398.2015.1077195

[57] Melnikova, N., Burlova, I., Kiseleva, T., Klabukova, I., Gulenova, M., Kislitsin, C.A., Vasin, V. and Tanaseichuk, B. (2012) A Practical Synthesis of Betulonic Acid Using Selective Oxidation of Betulin on Aluminium Solid Support. Molecules, 17, 11849-11863. https://doi.org/10.3390/molecules171011849

[58] Ekor, M. (2014) The Growing Use of Herbal Medicines: Issues Relating to Adverse Reactions and Challenges in Monitoring Safety. Frontiers in Pharmacology, 4, 177. https://doi.org/10.3389/fphar.2013.00177

[59] Heber, D. (2004) Phytochemicals beyond Antioxidation. The Journal of Nutrition, 134, 3175S-3176S. https://doi.org/10.1093/jn/134.11.3175S

[60] Ijaz, S., Akhtar, N., Khan, M.S., Hameed, A., Irfan, M., Arshad, M.A., Ali, S. and Asrar, M. (2018) Plant Derived Anticancer Agents: A Green Approach Towards Skin Cancers. Biomedicine \& Pharmacotherapy, 103, 1643-1651. https://doi.org/10.1016/j.biopha.2018.04.113

[61] Liu, R.H. (2013) Dietary Bioactive Compounds and Their Health Implications. Journal of Food Science, 78, A18-A25. https://doi.org/10.1111/1750-3841.12101

[62] López-Sepúlveda, R., Jiménez, R., Romero, M., Zarzuelo, M.J., Sánchez, M., Gómez-Guzmán, M., Vargas, F., O’Valle, F., Zarzuelo, A., Pérez-Vizcaíno, F. and Duarte, J. (2008) Wine Polyphenols Improve Endothelial Function in Large Vessels of Female Spontaneously Hypertensive Rats. Hypertension, 51, 1088-1095.

https://doi.org/10.1161/HYPERTENSIONAHA.107.107672 
[63] Serino, A. and Salazar, G. (2018) Protective Role of Polyphenols against Vascular Inflammation, Aging and Cardiovascular Disease. Nutrients, 11, 53. https://doi.org/10.3390/nu11010053

[64] Raffa, D., Maggio, B., Raimondi, M.V., Plescia, F. and Daidone, G. (2017) Recent Discoveries of Anticancer Flavonoids. European Journal of Medicinal Chemistry, 142, 213-228. https://doi.org/10.1016/j.ejmech.2017.07.034

[65] Wang, H.K. (2000) The Therapeutic Potential of Flavonoids. Expert Opinion on Investigational Drugs, 9, 2103-2119. https://doi.org/10.1517/13543784.9.9.2103

[66] Birt, D.F., Hendrich, S. and Wang, W. (2001) Dietary Agents in Cancer Prevention: Flavonoids and Isoflavonoids. Pharmacology \& Therapeutics, 90, 157-177. https://doi.org/10.1016/S0163-7258(01)00137-1

[67] Middleton Jr., E., Kandaswami, C. and Theoharides, T.C. (2000) The Effects of Plant Flavonoids on Mammalian Cells: Implications for Inflammation, Heart Disease, and Cancer. Pharmacological Reviews, 52, 673-751.

[68] Galati, G., Teng, S., Moridani, M.Y., Chan, T.S. and O’Brien, P.J. (2000) Cancer Chemoprevention and Apoptosis Mechanisms Induced by Dietary Polyphenolics. Drug Metabolism and Personalized Therapy, 17, 311-349. https://doi.org/10.1515/DMDI.2000.17.1-4.311

[69] Sparg, S.G., Light, M.E. and van Staden, J. (2004) Biological Activities and Distribution of Plant Saponins. Journal of Ethnopharmacology, 94, 219-243. https://doi.org/10.1016/j.jep.2004.05.016

[70] Yoshiki, Y., Kudou, S. and Okubo, K. (1998) Relationship between Chemical Structures and Biological Activities of Triterpenoid Saponins from Soybean. Bioscience, Biotechnology, and Biochemistry, 62, 2291-2299. https://doi.org/10.1271/bbb.62.2291

[71] Francis, G., Kerem, Z., Makkar, H.P.S. and Becker, K. (2002) The Biological Action of Saponins in Animal Systems: A Review. British Journal of Nutrition, 88, 587-605. https://doi.org/10.1079/BJN2002725

[72] Matsuura, H. (2001) Saponins in Garlic as Modifiers of the Risk of Cardiovascular Disease. The Journal of Nutrition, 131, 1000S-1005S. https://doi.org/10.1093/jn/131.3.1000S

[73] Vincken, J.P., Heng, L., de Groot, A. and Gruppen, H. (2007) Saponins, Classification and Occurrence in the Plant Kingdom. Phytochemistry, 68, 275-297. https://doi.org/10.1016/j.phytochem.2006.10.008

[74] Smith, B.N. and Dilger, R.N. (2018) Immunomodulatory Potential of Dietary Soybean-Derived Isoflavones and Saponins in Pigs. Journal of Animal Science, 96, 1288-1304. https://doi.org/10.1093/jas/sky036

[75] Wang, Y., Zhang, Y., Zhu, Z., et al. (2007) Exploration of the Correlation between the Structure, Hemolytic Activity, and Cytotoxicity of Steroid Saponins. Bioorganic \& Medicinal Chemistry, 15, 2528-2532. https://doi.org/10.1016/j.bmc.2007.01.058

[76] Bang, S.C., Seo, H.H., Shin, H.R., et al. (2008) A Convenient Preparation of a Disaccharide Motif and Its Role in the Cytotoxicity of the Triterpenoid Saponin, Alpha-Hederin. Archives of Pharmacal Research, 31, 555-561. https://doi.org/10.1007/s12272-001-1192-7

[77] Mimaki, Y., Yokosuka, A., Kuroda, M. and Sashida, Y. (2001) Cytotoxic Activities and Structure-Cytotoxic Relationships of Steroidal Saponins. Biological and Pharmaceutical Bulletin, 24, 1286-1289. https://doi.org/10.1248/bpb.24.1286

[78] De Marino, S., Iorizzi, M., Palagiano, E., Zollo, F. and Roussakis, C. (1998) Starfish 
Saponins. 55. Isolation, Structure Elucidation, and Biological Activity of the Steroid Oligoglycosides from an Antarctic Starfish of the Family Asteriidae. Journal of Natural Products, 61, 1319-1327. https://doi.org/10.1021/np970500e

[79] Podolak, I., Galanty, A. and Sobolewska, D. (2010) Saponins as Cytotoxic Agents: A Review. Phytochemistry Reviews, 9, 425-474.

https://doi.org/10.1007/s11101-010-9183-Z

[80] Lemeshko, V.V., Haridas, V., Quijano Perez, J.C. and Gutterman, J.U. (2006) Avicins, Natural Anticancer Saponins, Permeabilize Mitochondrial Membranes. Archives of Biochemistry and Biophysics, 454, 114-122. https://doi.org/10.1016/j.abb.2006.08.008

[81] Kang, J.H., Han, I.H., Sung, M.K., et al. (2008) Soybean Saponin Inhibits Tumor Cell Metastasis by Modulating Expressions of MMP-2, MMP-9 and TIMP-2. Cancer Letters, 261, 84-92. https://doi.org/10.1016/j.canlet.2007.11.006

[82] Ellington, A.A., Berhow, M. and Singletary, K.W. (2005) Induction of Macroautophagy in Human Colon Cancer Cells by Soybean B-Group Triterpenoid Saponins. Carcinogenesis, 26, 159-167. https://doi.org/10.1093/carcin/bgh297

[83] Gaidi, G., Marouf, A., Hanquet, B., et al. (2000) A New Major Triterpene Saponin from the Roots of Cucurbita Foetidissima. Journal of Natural Products, 63, 122-124. https://doi.org/10.1021/np9902800

[84] Parness, J. and Horwitz, S.B. (1981) Taxol Binds to Polymerized Tubulin in Vitro. The Journal of Cell Biology, 91, 479-487. https://doi.org/10.1083/jcb.91.2.479

[85] Faddeeva, M.D. and Beliaeva, T.N. (1997) Sanguinarine and Ellipticine Cytotoxic Alkaloids Isolated from Well-Known Antitumor Plants. Intracellular Targets of Their Action. Tsitologiia, 39, 181-208.

[86] Lu, J.J., Bao, J.L., Chen, X.P., Huang, M. and Wang, Y.T. (2012) Alkaloids Isolated from Natural Herbs as the Anticancer Agents. Evidence-Based Complementary and Alternative Medicine, 2012, Article ID: 485042. https://doi.org/10.1155/2012/485042

[87] Yared, J.A. and Tkaczuk, K.H. (2012) Update on Taxane Development: New Analogs and New Formulations. Drug Design, Development and Therapy, 6, 371-384. https://doi.org/10.2147/DDDT.S28997

[88] Isah, T. (2016) Anticancer Alkaloids from Trees: Development into Drugs. Pharmacognosy Reviews, 10, 90-99. https://doi.org/10.4103/0973-7847.194047

[89] Chen, K.S., Hsiao, Y.C., Kuo, D.Y., Chou, M.C., Chu, S.C., Hsieh, Y.S. and Lin, T.H. (2009) Tannic Acid-Induced Apoptosis and -Enhanced Sensitivity to Arsenic Trioxide in Human Leukemia HL-60 Cells. Leukemia Research, 33, 297-307. https://doi.org/10.1016/j.leukres.2008.08.006

[90] Sakagami, H., Jiang, Y., Kusama, K., Atsumi, T., Ueha, T., Toguchi, M., Iwakura, I., Satoh, K., Ito, H., Hatano, T. and Yoshida, T. (2000) Cytotoxic Activity of Hydrolyzable Tannins against Human Oral Tumor Cell Lines-A Possible Mechanism. Phytomedicine, 7, 39-47. https://doi.org/10.1016/S0944-7113(00)80020-3

[91] Tikoo, K., Sane, M.S. and Gupta, C. (2011) Tannic Acid Ameliorates Doxorubicin-Induced Cardiotoxicity and Potentiates Its Anti-Cancer Activity: Potential Role of Tannins in Cancer Chemotherapy. Toxicology and Applied Pharmacology, 251, 191-200. https://doi.org/10.1016/j.taap.2010.12.012

[92] Okuda, T. (2005) Systematics and Health Effects of Chemically Distinct Tannins in Medicinal Plants. Phytochemistry, 66, 2012-2031.

https://doi.org/10.1016/j.phytochem.2005.04.023 
[93] Balunas, M.J. and Kinghorn, A.D. (2005) Drug Discovery from Medicinal Plants. Life Sciences, 78, 431-441. https://doi.org/10.1016/j.lfs.2005.09.012

[94] Diederich, M., Muller, F. and Cerella, C. (2017) Cardiac Glycosides: From Molecular Targets to Immunogenic Cell Death. Biochemical Pharmacology, 125, 1-11. https://doi.org/10.1016/j.bcp.2016.08.017

[95] Schneider, N.F.Z., Cerella, C., Simões, C.M.O. and Diederich, M. (2017) Anticancer and Immunogenic Properties of Cardiac Glycosides. Molecules, 22, 1932. https://doi.org/10.3390/molecules22111932

[96] Molassiotis, A., Fernández-Ortega, P., Pud, D., Ozden, G., Scott, J.A., Panteli, V., Margulies, A., Browall, M., Magri, M., Selvekerova, S., Madsen, E., Milovics, L., Bruyns, I., Gudmundsdottir, G., Hummerston, S., Ahmad, A.M., Platin, N., Kearney, N. and Patiraki, E. (2005) Use of Complementary and Alternative Medicine in Cancer Patients: A European Survey. Annals of Oncology, 16, 655-663.

https://doi.org/10.1093/annonc/mdi110

[97] Cragg, G.M. and Newman, D.J. (2005) Plants as a Source of Anti-Cancer Agents. Journal of Ethnopharmacology, 100, 72-79. https://doi.org/10.1016/j.jep.2005.05.011

[98] Harvey, A.L. (1999) Medicines from Nature: Are Natural Products Still Relevant to Drug Discovery? Trends in Pharmacological Sciences, 20, 196-198. https://doi.org/10.1016/S0165-6147(99)01346-2

[99] Schröder, S., Lee, S., Efferth, T. and Motoo, Y. (2013) Acupuncture and Herbal Medicine for Cancer Patients. Evidence-Based Complementary and Alternative Medicine, 2013, Article ID: 313751. https://doi.org/10.1155/2013/313751

[100] Damery, S., Gratus, C., Grieve, R., Warmington, S., Jones, J., Routledge, P., Greenfield, S., Dowswell, G., Sherriff, J. and Wilson, S. (2011) The Use of Herbal Medicines by People with Cancer: A Cross-Sectional Survey. British Journal of Cancer, 104, 927-933. https://doi.org/10.1038/bjc.2011.47

[101] Van der Heijden, R., Jacobs, D.I., Snoeijer, W., Hallard, D. and Verpoorte, R. (2004) The Catharanthus Alkaloids: Pharmacognosy and Biotechnology. Current Medicinal Chemistry, 11, 1241-1253. https://doi.org/10.2174/0929867043455846

[102] Clark, P.I. and Slevin, M.L. (1987) The Clinical Pharmacology of Etoposide and Teniposide. Clinical Pharmacokinetics, 12, 223-252. https://doi.org/10.2165/00003088-198712040-00001

[103] Slevin, M.L. (1991) The Clinical Pharmacology of Etoposide. Cancer, 67, 319-329.

[104] Najar, I.A. and Johri, R.K. (2014) Pharmaceutical and Pharmacological Approaches for Bioavailability Enhancement of Etoposide. Journal of Biosciences, 39, 139-144. https://doi.org/10.1007/s12038-013-9399-3

[105] Horwitz, S.B. (2004) Personal Recollections on the Early Development of Taxol. Journal of Natural Products, 67, 136-138. https://doi.org/10.1021/np0304464

[106] Han, H.J., Tan, N.H., Zeng, G.Z., Fan, J.T., Huang, H.Q., Ji, C.J., Jia, R.R., Zhao, Q.S., Zhang, Y.J., Hao, X.J. and Wang, L.Q. (2008) Natural Inhibitors of DNA Topoisomerase I with Cytotoxicities. Chemistry \& Biodiversity, 5, 1364-1368. https://doi.org/10.1002/cbdv.200890124

[107] Kumar, S., Mahdi, H., Bryant, C., Shah, J.P., Garg, G. and Munkarah, A. (2010) Clinical Trials and Progress with Paclitaxel in Ovarian Cancer. International Journal of Women's Health, 2, 411-427. https://doi.org/10.2147/IJWH.S7012

[108] Cragg, G.M. and Newman, D.J. (2004) A Tale of Two Tumor Targets: Topoisomerase I and Tubulin. The Wall and Wani Contribution to Cancer Chemotherapy. 
Journal of Natural Products, 67, 232-244. https://doi.org/10.1021/np030420c

[109] Takeuchi, I. and Makino, K. (2019) Biocompatibility and Effectiveness of Paclitaxel-Encapsulated Micelle Using Phosphoester Compounds as a Carrier for Cancer Treatment. Colloids and Surfaces B: Biointerfaces, 177, 356-361. https://doi.org/10.1016/j.colsurfb.2019.02.017

[110] Bhattacharya, S.K., Bhattacharya, A., Sairam, K. and Ghosal, S. (2000) Anxiolytic-Antidepressant Activity of Withania somnifera Glycowithanolides: An Experimental Study. Phytomedicine, 7, 463-469. https://doi.org/10.1016/S0944-7113(00)80030-6

[111] Wall, M.E. and Wani, M.C. (1996) Camptothecin and Taxol: From Discovery to Clinic. Journal of Ethnopharmacology, 51, 239-253. https://doi.org/10.1016/0378-8741(95)01367-9

[112] Cunha, K.S., Reguly, M.L., Graf, U. and Rodrigues de Andrade, H.H. (2002) Comparison of Camptothecin Derivatives Presently in Clinical Trials: Genotoxic Potency and Mitotic Recombination. Mutagenesis, 17, 141-147. https://doi.org/10.1093/mutage/17.2.141

[113] Adams, M. and Jewell, A.P. (2007) The Use of Complementary and Alternative Medicine by Cancer Patients. International Seminars in Surgical Oncology, 4, 10. https://doi.org/10.1186/1477-7800-4-10

[114] Pouget, C., Lauthier, F., Simon, A., Fagnere, C., Basly, J.P., Delage, C. and Chulia, A.J. (2001) Flavonoids: Structural Requirements for Antiproliferative Activity on Breast Cancer Cells. Bioorganic \& Medicinal Chemistry Letters, 11, 3095-3097. https://doi.org/10.1016/S0960-894X(01)00617-5

[115] Schiavano, G.F., De Santi, M., Brandi, G., Fanelli, M., Bucchini, A., Giamperi, L. and Giomaro, G. (2015) Inhibition of Breast Cancer Cell Proliferation and in Vitro Tumorigenesis by a New Red Apple Cultivar. PLOS ONE, 10, e0135840. https://doi.org/10.1371/journal.pone.0135840

[116] Zhu, X., Sui, M. and Fan, W. (2005) In Vitro and in Vivo Characterizations of Tetrandrine on the Reversal of P-Glycoprotein-Mediated Drug Resistance to Paclitaxel. Anticancer Research, 25, 1953-1962.

[117] De Bono, A., Capuano, B. and Scammells, P.J. (2015) Progress toward the Development of Noscapine and Derivatives as Anticancer Agents. Journal of Medicinal Chemistry, 58, 5699-5727. https://doi.org/10.1021/jm501180v

[118] Sajadian, S., Vatankhah, M., Majdzadeh, M., Kouhsari, S.M., Ghahremani, M.H., Ostad, S.N. (2015) Cell Cycle Arrest and Apoptogenic Properties of Opium Alkaloids Noscapine and Papaverine on Breast Cancer Stem Cells. Toxicology Mechanisms and Methods, 25, 388-395. https://doi.org/10.3109/15376516.2015.1045656

[119] Oberlies, N.H. and Kroll, D.J. (2004) Camptothecin and Taxol: Historic Achievements in Natural Products Research. Journal of Natural Products, 67, 129-135. https://doi.org/10.1021/np030498t

[120] Haridas, V., Higuchi, M., Jayatilake, G.S., Bailey, D., Mujoo, K., Blake, M.E., Arntzen, C.J. and Gutterman, J.U. (2001) Avicins: Triterpenoid Saponins from Acacia victoriae (Bentham) Induce Apoptosis by Mitochondrial Perturbation. Proceedings of the National Academy of Sciences of the United States of America, 98, 5821-5826. https://doi.org/10.1073/pnas.101619098

[121] Alam, F., Najum, U., Saqib, Q. and Waheed, A. (2017) Cytotoxic Activity of Extracts and Crude Saponins from Zanthoxylum armatum DC. against Human Breast (MCF-7, MDA-MB-468) and Colorectal (Caco-2) Cancer Cell Lines. BMC Complementary and Alternative Medicine, 17, 368. 
https://doi.org/10.1186/s12906-017-1882-1

[122] González-Sarrías, A., Yuan, T. and Seeram, N.P. (2012) Cytotoxicity and Structure Activity Relationship Studies of Maplexins A-I, Gallotannins from Red Maple (Acer rubrum). Food and Chemical Toxicology, 50, 1369-1376.

https://doi.org/10.1016/j.fct.2012.02.031

[123] Barrajón-Catalán, E., Fernández-Arroyo, S., Saura, D., Guillén, E., Fernández-Gutiérrez, A., Segura-Carretero, A. and Micol, V. (2010) Cistaceae aqueous Extracts Containing Ellagitannins Show Antioxidant and Antimicrobial Capacity, and Cytotoxic Activity against Human Cancer Cells. Food and Chemical Toxicology, 48, 2273-2282. https://doi.org/10.1016/j.fct.2010.05.060

[124] Winnicka, K., Bielawski, K. and Bielawska, A. (2006) Cardiac Glycosides in Cancer Research and Cancer Therapy. Acta Poloniae Pharmaceutica, 63, 109-115.

[125] Calderón-Montaño, J.M., Burgos-Morón, E., Orta, M.L., Maldonado-Navas, D., García-Domínguez, I. and López-Lázaro, M. (2014) Evaluating the Cancer Therapeutic Potential of Cardiac Glycosides. BioMed Research International, 2014, Article ID: 794930. https://doi.org/10.1155/2014/794930

[126] Wang, I.K., Lin-Shiau, S.Y. and Lin, J.K. (1999) Induction of Apoptosis by Apigenin and Related Flavonoids through Cytochrome c Release and Activation of Caspase-9 and Caspase-3 in Leukaemia HL-60 Cells. European Journal of Cancer, 35, $1517-1525$.

[127] Chung, H.S., Chang, L.C., Lee, S.K., Shamon, L.A., van Breemen, R.B., Mehta, R.G., Farnsworth, N.R., Pezzuto, J.M. and Kinghorn, A.D. (1999) Flavonoid Constituents of Chorizanthe diffusa with Potential Cancer Chemopreventive Activity. Journal of Agricultural and Food Chemistry, 47, 36-41. https://doi.org/10.1021/jf980784o

[128] Csokay, B., Prajda, N., Weber, G. and Olah, E. (1997) Molecular Mechanisms in the Antiproliferative Action of Quercetin. Life Sciences, 60, 2157-2163. https://doi.org/10.1016/S0024-3205(97)00230-0

[129] De Vincenzo, R., Ferlini, C., Distefano, M., Gaggini, C., Riva, A., Bombardelli, E., Morazzoni, P., Valenti, P., Belluti, F., Ranelletti, F.O., Mancuso, S. and Scambia, G. (2000) In Vitro Evaluation of Newly Developed Chalcone Analogues in Human Cancer Cells. Cancer Chemotherapy and Pharmacology, 46, 305-312. https://doi.org/10.1007/s002800000160

[130] Zhu, H. and Gooderham, N.J. (2006) Mechanisms of Induction of Cell Cycle Arrest and Cell Death by Cryptolepine in Human Lung Adenocarcinoma A549 Cells. Toxicological Sciences, 91, 132-139. https://doi.org/10.1093/toxsci/kfj146

[131] Matsui, T.A., Sowa, Y., Murata, H., Takagi, K., Nakanishi, R., Aoki, S., Yoshikawa, M., Kobayashi, M., Sakabe, T., Kubo, T. and Sakai, T. (2007) The Plant Alkaloid Cryptolepine Induces p21WAF1/CIP1 and Cell Cycle Arrest in a Human Osteosarcoma Cell Line. International Journal of Oncology, 31, 915-922.

https://doi.org/10.3892/ijo.31.4.915

[132] Laryea, D., Isaksson, A., Wright, C.W., Larsson, R. and Nygren, P. (2009) Characterization of the Cytotoxic Activity of the Indoloquinoline Alkaloid Cryptolepine in Human Tumour Cell Lines and Primary Cultures of Tumour Cells from Patients. Invest New Drugs, 27, 402-411. https://doi.org/10.1007/s10637-008-9185-5

[133] Zhang, Y., Peng, Y., Li, L., Zhao, L., Hu, Y., Hu, C. and Song, S. (2013) Studies on Cytotoxic Triterpene Saponins from the Leaves of Aralia elata. Food Chemistry, 138, 208-213. https://doi.org/10.1016/j.foodchem.2012.10.041

[134] Kawazoe, N., Watabe, M., Masuda, Y., Nakajo, S. and Nakaya, K. (1999) Tiam1 Is Involved in the Regulation of Bufalin-Induced Apoptosis in Human Leukemia Cells. 
Oncogene, 18, 2413-2421. https://doi.org/10.1038/sj.onc.1202555

[135] Watabe, M., Kawazoe, N., Masuda, Y., Nakajo, S. and Nakaya, K. (1997) Bcl-2 Protein Inhibits Bufalin-Induced Apoptosis through Inhibition of Mitogen-Activated Protein Kinase Activation in Human Leukemia U937 Cells. Cancer Research, 57, 3097-3100.

[136] Kajimoto, S., Takanashi, N., Kajimoto, T., Xu, M., Cao, J., Masuda, Y., Aiuchi, T., Nakajo, S., Ida, Y. and Nakaya, K. (2002) Sophoranone, Extracted from a Traditional Chinese Medicine Shan Dou Gen, Induces Apoptosis in Human Leukemia U937 Cells via Formation of Reactive Oxygen Species and Opening of Mitochondrial Permeability Transition Pores. International Journal of Cancer, 99, 879-890.

https://doi.org/10.1002/ijc.10414

[137] Qian, M., Li, Y., Li, S.-L., Jie, Y., Zhang, P.-H. and Qiang, W. (2014) Chemical Profiles and Anticancer Effects of Saponin Fractions of Different Polarity from the Leaves of Panax notoginseng. Chinese Journal of Natural Medicines, 12, 30-37. https://doi.org/10.1016/S1875-5364(14)60006-6

[138] Wenzel, U., Kuntz, S., Brendel, M.D. and Daniel, H. (2000) Dietary Flavone Is a Potent Apoptosis Inducer in Human Colon Carcinoma Cells. Cancer Research, 60, 3823-3831.

[139] Alam, M.N., Almoyad, M. and Huq, F. (2018) Polyphenols in Colorectal Cancer: Current State of Knowledge including Clinical Trials and Molecular Mechanism of Action. BioMed Research International, 2018, Article ID: 4154185. https://doi.org/10.1155/2018/4154185

[140] Popłoński, J., Turlej, E., Sordon, S., Tronina, T., Bartmańska, A., Wietrzyk, J. and Huszcza, E. (2018) Synthesis and Antiproliferative Activity of Minor Hops Prenylflavonoids and New Insights on Prenyl Group Cyclization. Molecules, 23, 776. https://doi.org/10.3390/molecules23040776

[141] Liu, Y., Zhang, J., Feng, S., Zhao, T., Li, Z., Wang, L., Wang, P., Du, H., Yuan, S. and Sun, L. (2018) A Novel Camptothecin Derivative 3j Inhibits Nsclc Proliferation Via Induction of Cell Cycle Arrest By Topo I-Mediated DNA Damage. Anti-Cancer in Medicinal Chemistry, 19. https://doi.org/10.2174/1871520619666181207102037

[142] Creemers, G., Bolis, G., Gore, M., Scarfone, G., Lacave, A.J., Guastalla, J.P., Despax, R., Favalli, G., Kreinberg, R., Van Belle, S., Hudson, I., Verweij, J. and Ten Bokkel Huinink, W.W. (1996) Topotecan, an Active Drug in the Second-Line Treatment of Epithelial Ovarian Cancer: Results of a Large European Phase II Study. Journal of Clinical Oncology, 14, 3056-3061. https://doi.org/10.1200/JCO.1996.14.12.3056

[143] Prewett, M.C., Hooper, A.T., Bassi, R., Ellis, L.M., Waksal, H.W. and Hicklin, D.J. (2002) Enhanced Antitumor Activity of Anti-Epidermal Growth Factor Receptor Monoclonal Antibody IMC-C225 in Combination with Irinotecan (CPT-11) against Human Colorectal Tumor Xenografts. Clinical Cancer Research, 8, 994-1003.

[144] Li, Q.C., Liang, Y., Tian, Y. and Hu, G.R. (2016) Arctigenin Induces Apoptosis in Colon Cancer Cells through ROS/p38MAPK Pathway. Journal of BUON, 21, 87-94.

[145] Tin, M.M., Cho, C.H., Chan, K., James, A.E. and Ko, J.K. (2007) Astragalus Saponins Induce Growth Inhibition and Apoptosis in Human Colon Cancer Cells and Tumor Xenograft. Carcinogenesis, 28, 1347-1355. https://doi.org/10.1093/carcin/bgl238

[146] Tong, Q.Y., He, Y., Zhao, Q.B., Qing, Y., Huang, W. and Wu, X.H. (2012) Cytotoxicity and Apoptosis-Inducing Effect of Steroidal Saponins from Dioscorea Zingiberensis Wright against Cancer Cells. Steroids, 77, 1219-1227. 
https://doi.org/10.1016/j.steroids.2012.04.019

[147] Seeram, N.P., Adams, L.S., Henning, S.M., Niu, Y., Zhang, Y., Nair, M.G. and Heber, D. (2005) In Vitro Antiproliferative, Apoptotic and Antioxidant Activities of Punicalagin, Ellagic Acid and a Total Pomegranate Tannin Extract Are Enhanced in Combination with Other Polyphenols as Found in Pomegranate Juice. The Journal of Nutritional Biochemistry, 16, 360-367.

[148] Larrosa, M., Tomás-Barberán, F.A. and Espín, J.C. (2006) The Dietary Hydrolysable Tannin Punicalagin Releases Ellagic Acid that Induces Apoptosis in Human Colon Adenocarcinoma Caco-2 Cells by Using the Mitochondrial Pathway. The Journal of Nutritional Biochemistry, 17, 611-625. https://doi.org/10.1016/j.jnutbio.2005.09.004

[149] Shi, Y.Q., Fukai, T., Sakagami, H., Chang, W.J., Yang, P.Q., Wang, F.P. and Nomura, T. (2001) Cytotoxic Flavonoids with Isoprenoid Groups from Morus mongolica. Journal of Natural Products, 64, 181-188. https://doi.org/10.1021/np000317c

[150] Fukai, T., Sakagami, H., Toguchi, M., Takayama, F., Iwakura, I., Atsumi, T., Ueha, T., Nakashima, H. and Nomura, T. (2000) Cytotoxic Activity of Low Molecular Weight Polyphenols against Human Oral Tumor Cell Lines. Anticancer Research, 20, 2525-2536.

[151] Sakagami, H., Jiang, Y., Kusama, K., Atsumi, T., Ueha, T., Toguchi, M., Iwakura, I., Satoh, K., Fukai, T. and Nomura, T. (2000) Induction of Apoptosis by Flavones, Flavonols(3-Hydroxyflavones) and Isoprenoid-Substituted Flavonoids in Human Oral Tumor Cell Lines. Anticancer Research, 20, 271-277.

[152] Elattar, T.M. and Virji, A.S. (2000) Effect of Tea Polyphenols on Growth of Oral Squamous Carcinoma Cells in Vitro. Anticancer Research, 20, 3459-3465.

[153] Elattar, T.M. and Virji, A.S. (2000) The Inhibitory Effect of Curcumin, Genistein, Quercetin and Cisplatin on the Growth of Oral Cancer Cells in Vitro. Anticancer Research, 20, 1733-1738.

[154] Bai, F., Matsui, T., Ohtani-Fujita, N., Matsukawa, Y., Ding, Y. and Sakai, T. (1998) Promoter Activation and Following Induction of the p21/WAF1 Gene by Flavone Is Involved in $\mathrm{G}_{1}$ Phase Arrest in A549 Lung Adenocarcinoma Cells. FEBS Letters, 437, 61-64. https://doi.org/10.1016/S0014-5793(98)01198-3

[155] Caltagirone, S., Ranelletti, F.O., Rinelli, A., Maggiano, N., Colasante, A., Musiani, P., Aiello, F.B. and Piantelli, M. (1997) Interaction with Type II Estrogen Binding Sites and Antiproliferative Activity of Tamoxifen and Quercetin in Human Non-Small-Cell Lung Cancer. American Journal of Respiratory Cell and Molecular Biology, 17, 51-59. https://doi.org/10.1165/ajrcmb.17.1.2728

[156] Ganguly, A., Yang, H. and Cabral, F. (2010) Paclitaxel-Dependent Cell Lines Reveal a Novel Drug Activity. Molecular Cancer Therapeutics, 9, 2914-2923.

https://doi.org/10.1158/1535-7163.MCT-10-0552

[157] Ahsan, H., Reagan-Shaw, S., Breur, J. and Ahmad, N. (2007) Sanguinarine Induces Apoptosis of Human Pancreatic Carcinoma AsPC-1 and BxPC-3 Cells via Modulations in Bcl-Family Proteins. Cancer Letters, 249,198-208.

https://doi.org/10.1016/j.canlet.2006.08.018

[158] Johansson, S., Lindholm, P., Gullbo, J., Larsson, R., Bohlin, L. and Claeson, P. (2001) Cytotoxicity of Digitoxin and Related Cardiac Glycosides in Human Tumor Cells. Anti-Cancer Drugs, 12, 475-483. https://doi.org/10.1097/00001813-200106000-00009

[159] Ajazuddin, S.S. (2012) Legal Regulations of Complementary and Alternative Medicines in Different Countries. Pharmacogn Review, 6, 154-160. 
https://doi.org/10.4103/0973-7847.99950

[160] Iqbal, J., Abbasi, B.A., Ahmad, R., Batool, R., Mahmood, T., Ali, B., Khalil, A.T., Kanwal, S., Afzal Shah, S., Alam, M.M., Bashir, S., Badshah, H. and Munir, A. (2019) Potential Phytochemicals in the Fight against Skin Cancer: Current Landscape and Future Perspectives. Biomedicine \& Pharmacotherapy, 109, 1381-1393. https://doi.org/10.1016/j.biopha.2018.10.107

[161] Desai, A.G., Qazi, G.N., Ganju, R.K., El-Tamer, M., Singh, J., Saxena, A.K., Bedi, Y.S., Taneja, S.C. and Bhat, H.K. (2008) Medicinal Plants and Cancer Chemoprevention. Current Drug Metabolism, 9, 581-591.

https://doi.org/10.2174/138920008785821657

[162] Greenwell, M. and Rahman, P.K. (2015) Medicinal Plants: Their Use in Anticancer Treatment. International Journal of Pharmaceutical Sciences and Research, 6, 4103-4112.

[163] Gezici, S. and Șekeroğlu, N. (2018) Current Perspectives in the Application of Medicinal Plants against Cancer: Novel Therapeutic Agents. Anti-Cancer Agents in Medicinal Chemistry, 19, 101-111.

[164] Futreal, P.A., Coin, L., Marshall, M., Down, T., Hubbard, T., Wooster, R., Rahman, N. and Stratton, M.R. (2004) A Census of Human Cancer Genes. Nature Reviews Cancer, 4, 177-183. https://doi.org/10.1038/nrc1299

[165] Chan, C.W.H., Law, B.M.H., So, W.K.W., Chow, K.M. and Waye, M.M.Y. (2017) Novel Strategies on Personalized Medicine for Breast Cancer Treatment: An Update. International Journal of Molecular Sciences, 18, 2423. https://doi.org/10.3390/ijms18112423

[166] Newman, D.J., Cragg, G.M. and Snader, K.M. (2003) Natural Products as Sources of New Drugs over the Period 1981-2002. Journal of Natural Products, 66, 1022-1037. https://doi.org/10.1021/np0300961

[167] Yingchoncharoen, P., Kalinowski, D.S. and Richardson, D.R. (2016) Lipid-Based Drug Delivery Systems in Cancer Therapy: What Is Available and What Is Yet to Come. Pharmacological Reviews, 68, 701-787.

https://doi.org/10.1124/pr.115.012070

[168] Uramova, S., Kubatka, P., Dankova, Z., Kapinova, A., Zolakova, B., Samec, M., Zubor, P., Zulli, A., Valentova, V., Kwon, T.K., Solar, P., Kello, M., Kajo, K., Busselberg, D., Pec, M. and Danko, J. (2018) Plant Natural Modulators in Breast Cancer Prevention: Status Quo and Future Perspectives Reinforced by Predictive, Preventive, and Personalized Medical Approach. EPMA Journal, 9, 403-419. https://doi.org/10.1007/s13167-018-0154-6

[169] Ota, S., Singh, A., Srikanth, N., Sreedhar, B., Ruknuddin, G. and Dhiman, K.S. (2017) Chemical Characterization of an Ayurvedic Herbo-Mineral FormulationVasantakusumākara Rasa: A Potential Tool for Quality Assurance. Ancient Science of Life, 36, 207-214. https://doi.org/10.4103/asl.ASL 6617

[170] Atanasov, A.G., Waltenberger, B., Pferschy-Wenzig, E.M., Linder, T., Wawrosch, C., Uhrin, P., Temml, V., Wang, L., Schwaiger, S., Heiss, E.H., Rollinger, J.M., Schuster, D., Breuss, J.M., Bochkov, V., Mihovilovic, M.D., Kopp, B., Bauer, R., Dirsch, V.M. and Stuppner, H. (2015) Discovery and Resupply of Pharmacologically Active Plant-Derived Natural Products: A Review. Biotechnology Advances, 33, 1582-1614. https://doi.org/10.1016/j.biotechadv.2015.08.001

[171] Agarwal, G., Carcache, P.J.B., Addo, E.M. and Kinghorn, A.D. (2019) Current Status and Contemporary Approaches to the Discovery of Antitumor Agents from 
Higher Plants. Biotechnology Advances, in Press. https://doi.org/10.1016/j.biotechadv.2019.01.004

[172] Altemimi, A., Lakhssassi, N., Baharlouei, A., Watson, D.G. and Lightfoot, D.A. (2017) Phytochemicals: Extraction, Isolation, and Identification of Bioactive Compounds from Plant Extracts. Plants, 6, 42. https://doi.org/10.3390/plants6040042 